terialyi V Vserossiyskoy nauchno-prakticheskoy konferentsii s mezhdunarodnyim uchastiem. [Ecology and environmental management: applied aspects: proceedings of the V all-Russian scientific-practical conference with international participation]. Ufa: BSPU, 2015. Pp. 59-63.

2. Vdovin E.S. Tochnost opredeleniya ploschadey lesnyih strat po rezultatam klassifikatsii spektrozonalnyih snimkov na territorii respubliki Mariy El [The accuracy of determination of areas of forest strata according to the results of classification of multispectral imagery in the territory of the Republic of Mari El] Ezhemesyachnyiy nauchnyiy zhurnal [Monthly scientific journal]. SPb: Public research organization «Science and industry», 2015. № 2(7). Pp. 17-21.

3. Kaverin A.V. Ekologicheskie aspektyi ispolzovaniya agroresursnogo potentsiala (na osnove kontseptsii selskohozyaystvennoy ekonologii) [Environmental aspects of agroresource potential]. Saransk: Publishing House of Mordovian state University, 1996. 220 p.

4. Kaverin A.V. Ekologicheskoe planirovanie ispolzovaniya zemelnyih resursov Mordovii [Ecological land-use planning Mordovia].Vestnik mordovskogo universiteta[Bulletin of Mordovian state University]. 1992. № 4. Pp. 57-62.

5. Kurbanov E.A. Tematicheskoe kartirovanie i stratifikatsiya lesov Mariyskogo Zavolzhya po sputnikovyim snimkam Landsat [Thematic mapping and stratification of forests in middle zavolsgie by landsat satelite images] Vestnik Povolzhskogo gosudarstvennogo tehnologicheskogo universiteta. Seriya «Les. Ekologiya. Prirodopolzovanie» [Bulletin of the Volga region state technological University. A Series Of «Forest. Ecology. Environmental management»]. 2013. № 3. Pp. 82-92.

6. Manuhov V.F. Informacionnie tehnologii v aerokosmicheskoi podgotovke vipusknikov geografov-kartografov [Information technology in the aerospace graduate geographers-cartographers] Pedagogical Informatics. 2013. №2. Pp. 27-33.

7. Manuhov V.F. Ispolzovanie kosmicheskoy informatsii $\mathrm{v}$ protsesse uchebnoissledovatelskoy deyatelnosti studentov [The use of space-based information in the process of teaching and research activities of students] Geodeziya i kartografiya [Geodesy and cartography]. 2009. № 7. Pp. 44-48.

8. Rosyaikina E.A. Obrabotka dannyih distantsionnogo zondirovaniya zemli v gis-pakete Arcgis [Data processing of remote sensing in a GIS package Arcgis] Ogarev-online [The Ogarevonline]. Saransk. 2015. №4. Pp. 1-9. URL: http://journal.mrsu.ru/wpcontent/uploads/2015/02/Statya-Rosyajjkina-Ivlieva11.pdf (Reference date: 15.04.2015).

\title{
УДК 631.47
}

\section{А.Н. Махинов ${ }^{1}$, А.Ф. Махинова ${ }^{2}$}

\section{АНАЛИЗ ЭКОЛОГИЧЕСКОГО СОСТОЯНИЯ ЛАНДШАФТОВ ПРИ РАЗРАБОТКЕ МЕСТОРОЖДЕНИЙ ПРИОХОТЬЯ: МЕТОДЫ ОЦЕНКИ И КАРТОГРАФИРОВАНИЕ}

Резюме. Дана ландшафтно-геохимическая характеристика территории, показань источники загрязнения почв и поверхностных водотоков при разработке месторождения Кондер, расположенного в экстремальных природных условиях. Отражень условия и механизмы миграции элементов. Пространственная неоднородность кониентрачий химических элементов рассматривается как функция их миграционной активности в составе органоминеральных комплексов. Отражены условия и закономерности формирования природно-

\footnotetext{
${ }^{1}$ Институт водных и экологических проблем ДВО РАН, Хабаровск, 680000, Россия, зам. дир. по науке докт. геогр. н., проф. каф. инженерных систем и техносферной безопасности, ТОГУ; е-таil: amakhinov@mai.ru.

${ }^{2}$ Институт водных и экологических проблем ДВО РАН, Хабаровск, 680000, Россия, ст.н.с. канд. геогр.н., ст.н.с., лаб. экологии почв; e-mail: mahinova@ivep.as.khb.ru.
} 
техногенных почвенных структур. Показана роль природных и антропогенных факторов в формировании качества воды. Рассматриваются условия миграчии элементов в поверхностных водах различного происхождения. Сформулированы основные принципь экологически адаптированного к горным условиям северных районов Дальнего Востока режима природопользования.

Ключевые слова: ландиафты, химическое загрязнение, миграция.

Введение. Россия занимает третье место в мире по разведанным запасам золота, платины, а вместе с ЮАР поставляет на мировой рынок около 25\% платины, 65\% - золота и столько же палладия [Махинов и др., 2014]. Разработка и эксплуатация месторождений является одним из самых природоемких видов хозяйственной деятельности. Повышенный спрос на благородные металлы в мире способствует интенсификации их освоения. Извлечение платиноидов из природного сырья, за счет большой их потери при переработке, невелико. Поэтому одной из важнейших проблем золоторудной и платиноидной геологии Приохотья является расширение сырьевой базы россыпных месторождений. Свыше $60 \%$ россыпных месторождений, разрабатываемых в России, находятся на Дальнем Востоке. Благодаря неглубокому залеганию (6-10 м) обогащенных пластов и их малой мощности (0,6-2,0 м), рассыпные месторождения быстро вовлекаются в производство. Однако природные россыпи золота и платиноидов, как правило, характеризуются обедненностью запасов, наличием большого количества мелкого золота и поэтому требуют отчуждения больших земельных площадей и больших объемов воды для промывки пластов. И, в связи с этим, технология производства сопровождается обезлесиванием территорий, ухудшением качества земель и водных ресурсов, а большинство отвалов и хранилищ с миллионами тонн отходов еще долго будут являться источниками химического загрязнения окружающей среды [Alexandra $\mathrm{F}$ Makhinova, Alexey N. Makhinov, 2008].

Освоение россыпей в условиях сурового климата, горного рельефа и широкого распространения многолетнемерзлых пород, где восстановление нарушенных природных ландшафтов происходит крайне медленно, оказывает локальное, но интенсивное воздействие на многие компоненты ландшафтов. Острой проблемой является загрязнение почв тяжелыми металлами жидких и твердых отходов.

Разработка способов минимизации негативных последствий добывающих предприятий на почвенный покров невозможна без учета основных характеристик почв, геохимических и миграционных процессов, протекающих в почвенном пространстве. Выявление условий миграции и механизмов концентрации химических элементов в почвах являются одной из главнейших задач геохимии ландшафтов [Глазовская, 2007; Махинова и др., 2014]. В зоне землеотвода добывающих предприятий миграционную активность элементов в почвах контролируют условия почвообразования и техногенез. Почвообразование интенсифицирует геохимическую и миграционную активность элементов, техногенез поддерживает процессы их концентрирования.

Значительный ущерб для окружающей среды при разработке россыпных месторождений оказывает сброс промывочных сточных вод и отводное русло с большим количеством взвешенных частиц. Ливневые осадки способствуют взмучиванию и переливам сточных вод через борта хвостохранилищ, озер-отстойников и отводного водотока. Широкий спектр загрязняющих веществ делает крайне сложным анализ геохимического состояния почвенного покрова и поверхностных водотоков в зоне землеотвода, а недостаточная изученность территории затрудняют правильную интерпретацию имеющихся данных [Вернадский, 1980].

Цель работы заключалась в анализе динамических показателей концентраций загрязняющих элементов в почвах и природных водотоках для оценки: а) миграционной активности элементов; б) роли миграционных потоков в перераспределении элементов; в) условий, контролирующих механизмы миграции элементов в зависимости от географических факторов.

Материалы и методы исследований. Исследованы почвы и природные водотоки в пределах разрабатываемого месторождения Кондер (рис. 1). 


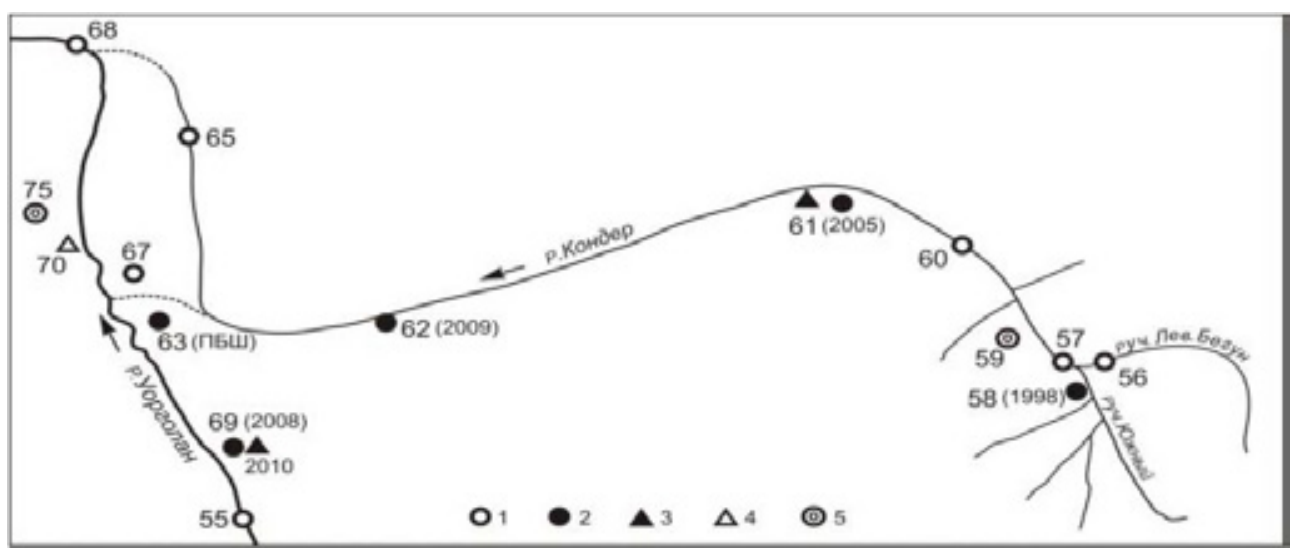

Puc. 1. Места отбора проб воды отстойников (1), воды рек и промышленных стоков (2), донных отложений (3), подземных вод (4), почвенных проб (5)

Исследования проводились на трех ключевых участках в бассейне р. Уорголан с различными гидрологическими особенностями поверхностных водотоков и водоемов. Пробы воды различных водных объектов проанализированы в аттестованных лабораториях ФГБУ ЦАС «Хабаровский» и МУП города Хабаровска «Водоканал» по общепринятым методикам.

Химический состав почв и донных отложений оценивали по результатам спектрального анализа с использованием метода ICP OES (эмиссионно-спектрометрический с индуктивно связанной плазмой на Спектроскане No 835 Lif 200). Особенное внимание было уделено анализу распространения сидерофильных (Fe, $\mathrm{Mn}, \mathrm{Cd}, \mathrm{Co}, \mathrm{Ni})$ и халькофильных $(\mathrm{Cu}, \mathrm{Zn}, \mathrm{Pb}$ ) элементов. Содержание общего углерода почвы, как основного фактора формирования геохимических потоков, определялись методом бихроматного окисления [Бельчикова, 1975, Махинова, 1989]. В работе использованы результаты авторов для сопредельных территорий. Численные значения множества концентраций химических элементов обработаны общепринятыми методами вариационной статистики [Смагин, 2003].

Полученные результаты для уникального в геолого-географическом отношении горного массива Кондер проанализированы с учетом его геолого-геохимических особенностей.

Природные условия. Кондёр - уникальное геологическое образование диаметром около 8 км с высотами 1200 - 1387 м над у.м., единственный в мире горный массив идеальной кольцеобразной формы (рис. 2). Он расположен в Аяно-Майском районе Хабаровского края в 90 км к западу-юго-западу от с. Нелькан и в 110 км к северу от с. Аян.

По физико-географическому районированию территория входит в состав Учурской провинции Байкальско-Становой области страны гор Южной Сибири и расположена в непосредственной близости с Северо-Джугджурской провинцией Джугджурской горной области страны Северо-Востока. Центральная часть массива сложена щелочно-ультраосновными изверженными породами. По всему массиву распространены секущие жильные и дайковые образования, представленные щелочными нефелин-сиенитовыми пегматитами. По периферии Кондерской интрузии располагаются карбонатиты в виде жил мощностью до 50 м. В северной части, где круг хребта размыкается, из него вытекает одноимённая река Кондер, приток Уорголана.

Разработка месторождения «Кондер» ведется открытым способом, большая часть карьеров находится в долине р. Кондер, которые являются источниками массированного загрязнения территории, расположенной ниже по течению. Мутность воды в реке распространяется на сотни километров. Загрязнение продолжается десятилетия спустя после окончания работ, поскольку незакрепленные растительностью отвалы продолжают размываться (рис. 3).

Специфическими природными условиями горного хребта Кондер являются:

1. Кольцевая форма с мягкими очертаниями форм рельефа в виде широких выположенных приводораздельных плато и неглубоко врезанных в него долин водотоков. За пределами хребта толща аллювиальных отложений возрастает и достигает 15 м в долине р. Уорголан. 
2. Продолжительная малоснежная зима с низкой температурой воздуха. Лето короткое, в любой день которого возможны отрицательные температуры. Количество годовых осадков колеблется от 650 до 800 мм [Новороцкий, 2007].

3. Многолетнемерзлые породы с глубиной сезонного оттаивания 0,2-0.3 м на переувлажненных грунтах и до 1,5 м на каменистых склонах южной экспозиции. Медленное оттаивание почв резко сокращает активный биологический период и влияет на формирование геохимических потоков и внутрипочвенный сток.

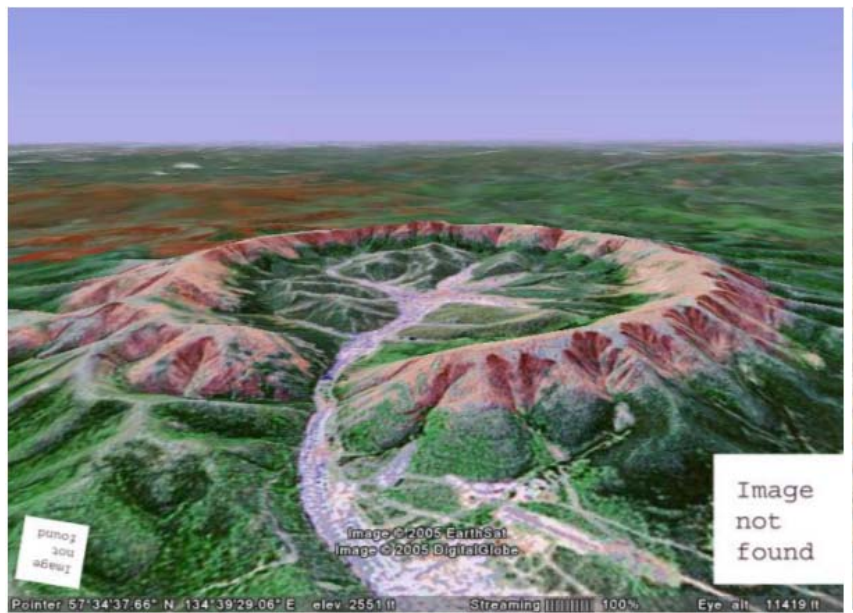

Puc. 2. Массив Кондер. GeoWiki, открытая энциклопедия, науки о Земле

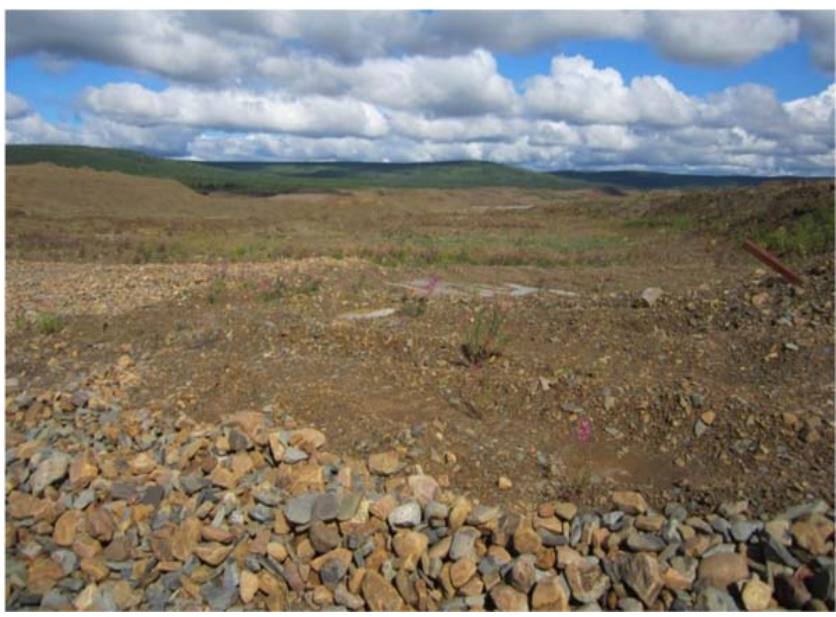

Puc. 3. Кондер, отвалы на участке после разработки, фото А.Н. Махинова

4. В горах хорошо выражена высотная поясность. Обширные площади гольцов венчают плоские водоразделы, которые ниже сменяются поясом кедрово-стланикового редколесья, переходящего в лиственничные леса. Для горных ландшафтов характерны интенсивный сток влаги, снос твердого вещества, инверсия холодного воздуха по склонам. В долинах наблюдается застаивание холодного воздуха и переувлажнение рыхлых отложений, где длительносезонная мерзлота влияет на поведение химических элементов.

5. Рекам свойственны высокие дождевые паводки, формирующиеся в июле-сентябре с интенсивной боковой эрозией берегов. Такой гидрологический режим не способствует аккумуляции илистых и глинистых частиц в донных отложениях рек, в их составе доминируют пески и гравий.

Технология извлечения металла. Разработка месторождения «Кондер» происходит посредством промывки рыхлой породы ударом водной струи. По степени промывистости пески имеют высокую степень сцементированности и относятся к труднопромывистым, расход воды, для $1 \mathrm{~m}^{3}$ их дезинтеграции составляет 8-12 $\mathrm{m}^{3}$. Под ударом водной струи по вращающемуся барабану с загруженной горной массой происходит дезинтеграция вещества, распыление микрочастиц внутри струи и их гидродиспергация. Гидродиспергация образуется внутри гидроструи и представляет собой химическое взаимодействие распыленных дисперсных частиц и ультрачастиц воды [Урьев, 1980].

Высокое содержание твердых гидродиспергируемых коллоидных частиц в песках способствует образованию суспензий [Muller and et., 1995]. Ударно встречное распыление микрочастиц обеспечивает переход в сточные воды различных растворимых макро- и микрокомпонентов. Размер частиц и их концентрация в суспензионных системах определяют высокую мутность и явление диффузии.

Ультрадисперсные суспензии, возникающие в зоне удара гидроструи, обладают рядом уникальных свойств - высокой степенью дисперсности минеральных частиц, особым энергетическим состоянием их поверхности и, как следствие геохимической сверхактивностью [Schukin and et., 1982]. 
Микрочастицы, образующиеся в результате удара гидроструи, обладают механической дисперсностью, имеют размер порядка: $\sim 7,4 * 10^{-5}$ м и огромную поверхностную энергию сорбционной емкости (En) [Schlegel and et., 2001].

Энергия сорбционной емкости $E_{\Pi}$ рассчитывается по уравнению:

$$
E n=\sigma S / m,
$$

где $S$ и $m$ - соответственно, площадь и масса единичной частицы, $\sigma$ - поправочный коэффициент, отражающий природу микрочастицы.

Открытый способ добычи драгметалла в долинах рек горного массива Кондер, способствует формированию различных источников загрязнения окружающей среды, к которым относятся:

- временные искусственные водоемы для обеспечения бесперебойной работы промывочных систем;

- отводные русла рек, проложенные по нарушенной поверхности;

- дренажные воды из карьеров по добыче горной массы для промывки;

- сточные воды отстойников, содержащие растворенные вещества и взвеси;

- отвалы породы, из которой талыми водами и дождевыми осадками выносятся тонкие фракции в почвы и водотоки;

- производственные площадки (склады, стоянки техники, ремонтные мастерские);

- грунтовые дороги, особенно на участках пересечения водотоков;

- бытовые сточные воды, свалки мусора и отходов жилых поселков.

Риски экологической безопасности в границах земельного отвода и прилегающей к нему территории определяются управлением выделенных источников загрязнения. Задача по управлению рисками негативных последствий эксплуатации месторождения остается крайне важной и требует создания многолетнего мониторинга [Касимов с соавт., 1989].

Результаты исследований и их обсуждение. Оценка техногенного воздействия и выявление механизмов загрязнения природных водотоков проводилась в долине руч. Кондер (рис. 4) на участках отработанных и действующих разработок месторождений.

Первый ключевой участок расположен внутри хребта Кондер в верхнем течении реки Кондер (разработки 2009 г.). Обследована система из 4-х озер-отстойников, часть из них самопроизвольно заросла травами и кустарниками (рис. 5). Испаряемость с водной поверхности слабая, цветность меняется от желтоватой до желтовато-бирюзовой. Обильное выпадение осадков в летний период увеличивает мутность в них и изменяет цветность. Циркуляция придонных щелочных вод, обусловленная широким распространением ультраосновных пород, влияет на механизмы агломерации дисперсных частиц и геохимические процессы в воде этих отстойников.

Экологическое состояние водных объектов зависит от возраста водоема и обнаруживает определенные закономерности распределения веществ в воде (табл. 1). Наибольшая кон-

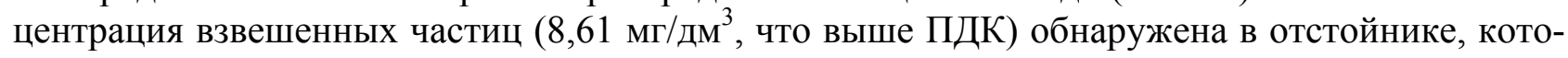
рый имеет консервацию 2009 года. Водоемы ранней консервации (2006-2007 г.) характеризуются показателями природного фона (pH 7,01-7,14, мутность менее 2,0 мг/дм ${ }^{3}$ ). Механизм снижения мутности простой и является следствием процессов коагуляции и агрегации механически диспергированных микрочастиц размером 2-3 мкм с их последующим осаждением и, соответственно, снижением мутности воды [Махинов с соавт. 2014].

Эффект поглощения слабо ориентированных молекул воды тонкими фракциями диспергированных частиц ведет к их химическому преобразованию, набуханию и медленному оседанию на дно отстойника, улучшая цветность воды [Урьев, 1980; Schlegel, 2001]. На цветность воды оказывают влияние и растворимые формы меди, железа. Анализ содержания загрязняющих веществ в исследованных водоемах выявил особенности их химического состава (табл. 1). Содер- 
жание химических веществ во всех исследованных водоемах и водотоках изменяется в широких пределах. Наименьшие значения концентраций всех элементов выявлены в истоках р. Кондер (ущелье), их содержание значительно ниже ПДК. Близкие к ним значения концентраций, за исключением алюминия, выявлены в отстойнике, образованном в 1998 г.

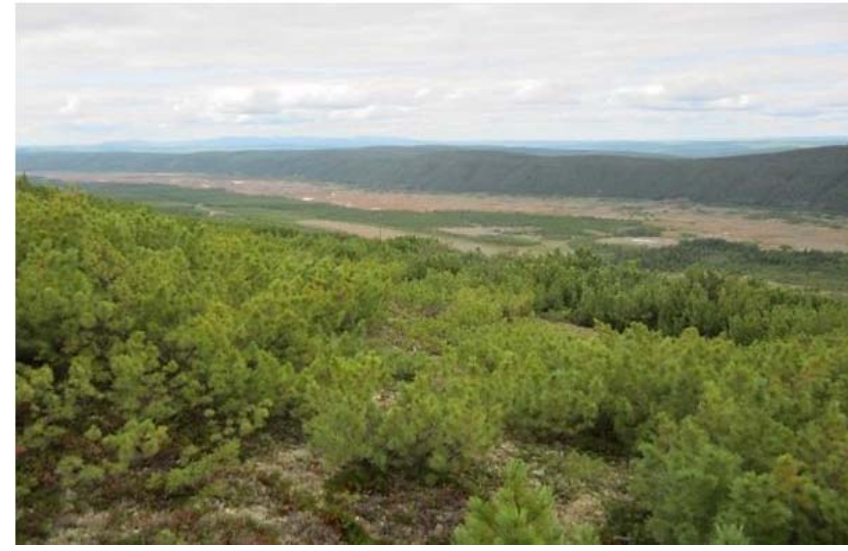

Puc. 4. Долина р. Кондер, фото А.Н. Махинова

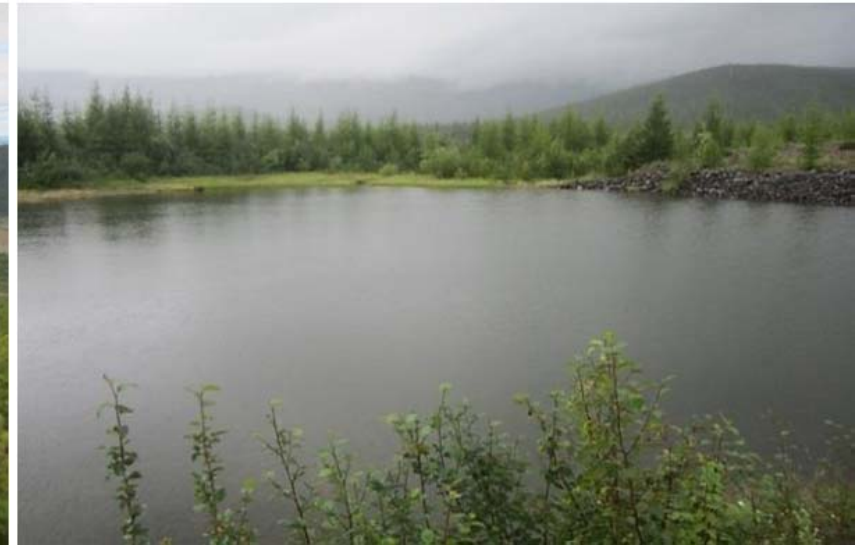

Puc. 5. Озеро-отстойник, фото А.Н. Махинова

Содержание основных компонентов в отработанных отстойниках

Таблища 1

\begin{tabular}{|c|c|c|c|c|c|c|c|c|c|c|c|}
\hline \multirow{3}{*}{$\begin{array}{c}\text { Наимено- } \\
\text { вание } \\
\text { участков и } \\
\text { точек отбо- } \\
\text { ра проб } \\
\end{array}$} & \multirow[t]{3}{*}{$\mathrm{pH}_{\mathrm{B}}$} & \multirow[t]{3}{*}{$\begin{array}{c}\text { Мутн } \\
\text { мг } \\
\text { /дм }\end{array}$} & \multirow{3}{*}{ 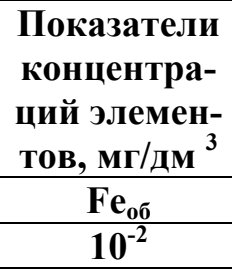 } & & & \multirow[b]{2}{*}{$\mathbf{C d}$} & \multirow{2}{*}{\multicolumn{2}{|c|}{$\mathbf{Z n}$}} & \multirow[b]{2}{*}{$\mathbf{C u}$} & \multirow[b]{2}{*}{$\mathbf{P b}$} & \\
\hline & & & & Al & Mn & & & & & & \\
\hline & & & & \multicolumn{8}{|c|}{$\mathrm{n10}^{-3}$} \\
\hline \multirow{4}{*}{$\begin{array}{l}\text { Отстойни- } \\
\text { ки и годы } \\
\text { их консер- } \\
\text { вации }\end{array}$} & $\begin{array}{l}\text { Центр } \\
\text { кольца- } \\
1998\end{array}$ & 7,14 & 7,11 & 42 & 104 & 5,1 & & 1,9 & 44 & 8.0 & 1,9 \\
\hline & $\begin{array}{l}152 \\
\text { линия- } \\
2006\end{array}$ & 7,01 & $>3,0$ & 22 & 6,0 & 4,3 & & 1,3 & 45 & 7,0 & 3,1 \\
\hline & $\begin{array}{l}\text { Ниже } \\
\text { кольца- } \\
2008\end{array}$ & 7,05 & $>3,0$ & 100 & 15 & 10 & & 2,0 & 21 & 11 & 2,0 \\
\hline & $\begin{array}{l}32 \text { линия- } \\
2009\end{array}$ & 7,11 & 8,61 & 235 & 109 & 6,2 & & 0,5 & 31 & 7,0 & 1,0 \\
\hline \multirow[t]{2}{*}{$\begin{array}{l}\text { Река } \\
\text { Кондер }\end{array}$} & $\begin{array}{l}\text { В центре } \\
\text { кольца }\end{array}$ & 7,15 & 4,12 & 33 & 77,0 & 5,0 & & 1,2 & 33 & 10 & 1,5 \\
\hline & В ущелье & 7,00 & $>3,0$ & 30 & 4,0 & 3,0 & &, 4 & 39 & 1,5 & 2,01 \\
\hline \multirow[t]{2}{*}{$\begin{array}{l}\text { Река } \\
\text { Уорголан }\end{array}$} & $\begin{array}{l}\text { Верхнее } \\
\text { течение }\end{array}$ & 7,05 & $>3,0$ & 0,10 & 0,08 & 0,1 & &, 01 & 0,11 & 1,0 & - \\
\hline & $\begin{array}{l}\text { Нижнее } \\
\text { течение }\end{array}$ & 7,09 & $<3,0$ & 8,13 & 4,7 & 1,4 & &, 14 & 0,33 & 12 & 0,03 \\
\hline \multicolumn{12}{|c|}{ Содержание тяжелых металлов в донных отложениях отстойников $\left(\mathrm{n}^{*} 10^{0}\right.$ в мг/кг) } \\
\hline \begin{tabular}{|l|} 
Отстойник \\
у пос. \\
Кондер \\
$(1998)$ \\
\end{tabular} & Не опр. & 43,4 & Не опр. & 0,60 & 79 & & 34 & & & 33 & \\
\hline $\begin{array}{l}\text { Отстойник } \\
692009 \text { г. }\end{array}$ & Не опр. & 49,9 & Не опр. & 0,40 & 44 & & 11 & & & 14 & \\
\hline \multicolumn{4}{|c|}{ ПДК-СанПин 2.14.1074-1(мг/дм $\left.{ }^{3}\right)$} & 7,21 & 1,5 & 30,0 & 50,0 & 10 & 1,0 & $50^{3}$ & $10^{3}$ \\
\hline
\end{tabular}


В отстойниках за пределами кольца (2008 и 2009 гг.) выявлены высокие концентрации железа $(100-235)^{*} 10^{-2}$ мг/дм ${ }^{3}$, слабо коррелирующие с показателями мутности. Не выявлено четкой корреляции между железом, алюминием и другими полиэлементами, что может быть связано с различными формами железа и их способностью к избирательности элементов для образования композиционных структур.

Особенности формирования качества сточных вод с позиции явления «сольватация $\rightarrow$ сорбция $\rightarrow$ седиментация» указывают на определенную избирательность элементов к сорбции с отрицательно заряженными фракциями диспергированных частиц. Последовательность взаимодействия полиэлементов в гетерогенных системах может быть обусловлена их композиционным составом. В концентрированных многокомпонентных растворах (болотные, сточные воды) возможно изоморфно гетеровалентное замещение $\mathrm{Al}^{+3} \mathrm{Ha} \mathrm{Fe}^{+3}$ в дисперсных глинистых минералах с образованием слабого заряда на поверхности. Явление сольватации определяется всеми видами электростатических взаимодействий в растворах ион $\rightarrow$ ион, ион $\rightarrow$ растворитель, растворитель $\rightarrow$ растворитель.

В водах отстойников при больших концентрациях взвесей, постоянно отталкивающиеся отрицательно заряженные диспергированные частицы способствуют явлениям сольватации с образованием композиционных структур полиэлементов и дальнейшей их сорбции на отрицательно заряженных микрочастицах [Шустов, 1995; Schukin and et., 1982]. Реакция среды водоемов в большей степени согласуется с поведением таких элементов, как $\mathrm{Fe}-\mathrm{Mn}, \mathrm{Fe}-$ $\mathrm{Mn}-\mathrm{Al}$ и т.д. (табл. 1).

Учитывая выше изложенное, можно предположить, что в сточных водах отстойников возможны полиэлементные композиции по железу: например композиции $\left\{\mathrm{Fe}^{+3} \rightarrow \mathrm{Mn}^{+7}\right.$ или $\left\{\mathrm{Fe}^{+3} \rightarrow \mathrm{Mn}^{+2(+5)} \rightarrow \mathrm{Al}^{+3}\right.$, в то время $\mathrm{Fe}^{+2}$ обладает большей вероятностью композиционного сродства к меди, цинку, например: $\left\{\mathrm{Fe}^{+2} \rightarrow \mathrm{Cu}^{+1(+2)} \rightarrow \mathrm{Pb}^{+1(+2)}\right.$ или $\left\{\mathrm{Fe}^{+2} \rightarrow \mathrm{Zn}^{+1(+2)}\right.$, что подтверждается и результатами анализов. Процессы сольватация $\rightarrow$ сорбция и(или) коагуляция $\rightarrow$ седиментация приводят к снижению концентрации полиэлементов и мутности в сточных водах и накоплению их в донных отложениях [Ивашов, 1994; Ивашов, Сиротский, 1996].

Донные отложения отстойников сложены тонкими фракциями ила мощностью до 50 см буровато-сизых оттенков с высокими концентрациями элементов. В донных отложениях отстойника-2009 содержание железа ниже (43,42 мг/кг), чем в отстойнике-1998 (49,97 мг/кг), что связано с временем осаждения. Содержание $\mathrm{Fe}$ в донных отложениях имеет превышения ПДК в 1,5-1,7 раз (ПДК 30 мг/кг), что позволяет отнести их к слабо загрязненным.

Концентрации $\mathrm{Zn}, \mathrm{Cu}$ и $\mathrm{Pb}$ в донных отложениях значительно выше, чем в сточных водах за счет процессов механического осаждения взвесей и сорбции растворенных комплексов на глинистых минералах. Формы существования полиметаллов в донных отложениях различны (соли, простые и двойные-гидраты, хелаты). Гидраты железа способны к образованию комплексных соединений, состав которых зависит от $\mathrm{pH}$ и температуры воды [Труфанов, 1975]. Сизо-голубые тона илов указывают на присутствие комплексных солей меди. Сорбция металлов и их комплексов донными отложениями зависит от 1) содержания металла в растворенной форме на контакте с донными отложениями и температуры воды и от 2) содержания в донных отложениях химически активных тонкодисперсных фракций, способных к сорбции. Большинство отстойников в настоящее время не представляют опасности.

Гидрохимические показатели проб воды р. Уорголан на отрезке ниже полигона обнаруживает превышения ПДК для $\mathrm{Fe}, \mathrm{Al}$ и $\mathrm{Mn}$, соответственно в 3; 1,6 и 2,8 раза. Содержание тяжелых металлов, таких как $\mathrm{Cd}, \mathrm{Cu}$ и $\mathrm{Pb}$ на отрезке ниже полигона показывает незначительное их превышение над таковыми выше полигона, что свидетельствует о поступлении их в составе механических взвесей через нижнюю дамбу.

Дренажные мерзлотные воды полигона по своим гидрохимическим показателям относятся к чистым и не оказывают влияния на загрязнение рек Кондер и Уорголан. Отводное русло р. Кондер течет преимущественно по старым отвалам и по гидрохимическим характеристикам слабо загрязнено. 
Для оценки распределения химических компонентов в почвенном пространстве бассейна р. Уорголан, использовали средние значения их аномальности (табл. 2).

Таблииа 2

Уровни аномальности химических компонентов в почвах (слой 0-20) на территории землеотвода

\begin{tabular}{|c|c|c|c|c|c|c|c|c|c|}
\hline \multirow[t]{2}{*}{$\begin{array}{c}\text { Участки отбора } \\
\text { проб в слое 0-20, } \\
2012-2015 \text { гг. }\end{array}$} & \multirow[t]{2}{*}{ pНв } & \multirow[t]{2}{*}{ Сорг \% } & \multirow[t]{2}{*}{$\begin{array}{c}\text { Средние значе- } \\
\text { ния уровней } \\
\text { аномальности } \\
\text { некоторых мик- } \\
\text { роэлементов, } \\
\text { слой } 0-20,{ }^{*} \text { Кк } \\
\mathrm{Fe}_{\mathrm{R}}\end{array}$} & & & & & & \\
\hline & & & & $\mathrm{Mn}$ & $\mathrm{Al}$ & $\mathrm{Pb}$ & $\mathrm{Cu}$ & $\mathrm{Zn}$ & $\mathrm{Cd}$ \\
\hline
\end{tabular}

Внутри хребта Кондер - 1-ый участок (отработанный)

\begin{tabular}{|l|l|l|l|l|l|l|l|l|l|}
\hline $\begin{array}{l}\text { Зона отвалов } \\
(50-120 \text { м) }\end{array}$ & 5,85 & 0,95 & 0,89 & 0,76 & 0,75 & 0,41 & 0,59 & 0,66 & 0,59 \\
\hline $\begin{array}{l}\text { В 200 м, органо- } \\
\text { минеральный }\end{array}$ & 5,61 & 6,14 & 0,74 & 0,68 & 0,74 & 0,41 & 0,48 & 0,34 & 0,22 \\
\hline $\begin{array}{l}\text { В 500 м, слабо- } \\
\text { оторфованный }\end{array}$ & 5,70 & 9,21 & 0,43 & 0,31 & 0,40 & 0,32 & 0,18 & 0,31 & 0,23 \\
\hline
\end{tabular}

Ниже разрабатываемого участка и ниже полигона, оторфованный (органо-минеральный)

\begin{tabular}{|l|l|l|l|l|l|l|l|l|l|}
\hline $\begin{array}{l}\text { Зона отвалов } \\
(50-100 \text { м) }\end{array}$ & 6,05 & 1,03 & 0,91 & 0,72 & 0,82 & 0,87 & 0,75 & 0,66 & 0,49 \\
\hline $\begin{array}{l}\text { В 150 м, слабо- } \\
\text { оторфованный }\end{array}$ & 5,91 & 4,76 & 0,63 & 0,54 & 0,41 & 0,61 & 0,58 & 0,24 & 0,21 \\
\hline $\begin{array}{l}\text { В 200 м, органо- } \\
\text { минеральный }\end{array}$ & 5,67 & 7,21 & 0,69 & 0,54 & 0,49 & 0,61 & 0,58 & 0,31 & 0,33 \\
\hline $\begin{array}{l}\text { В 230 м, } \\
\text { органогенный }\end{array}$ & 5,62 & 14,2 & 0,72 & 0,61 & 0,58 & 0,65 & 0,61 & 0,46 & 0,33 \\
\hline
\end{tabular}

Долина р. Уорголан - 2-ой участок (разрабатываемый)

\begin{tabular}{|c|c|c|c|c|c|c|c|c|c|}
\hline $\begin{array}{l}\text { Зона отвалов } \\
(70-100 \mathrm{M})\end{array}$ & 5,80 & 1,65 & 0,81 & 0,56 & 0,55 & 0,71 & 0,49 & 0,48 & 0,30 \\
\hline $\begin{array}{l}\text { В } 250 \text { м, органо- } \\
\text { минеральный }\end{array}$ & 5,80 & 7,84 & 0,66 & 0,48 & 0,61 & 0,62 & 0,28 & 0,30 & 0,20 \\
\hline $\begin{array}{l}\text { В } 500 \text { м слабо- } \\
\text { оторфованный }\end{array}$ & 5,90 & 9,81 & 0,49 & 0,33 & 0,40 & 0,32 & 0,18 & 0,21 & 0,13 \\
\hline \multicolumn{4}{|c|}{ **ТМ в почвах, мг/кг (по Виноградову, 1957) } & $\begin{array}{l}38^{*} \\
10^{3}\end{array}$ & 850 & 7130 & 10 & 20 & 50 \\
\hline
\end{tabular}

* Кк = Cvf/Cp- уровни аномальности характеризуют долю валовых форм в почвах от общего их содержания в породе;

** ТМ - тяжелые металлы.

Анализ распределения элементов в почвенном пространстве выявил следующие закономерности:

1) источники загрязнения оказывают влияние на содержание элементов в почвах, градиент их критического насыщения контролируют органические кислоты и тонкие фракции, способные к сорбции;

2) градиент критического насыщения интенсифицирует процессы окисления и определяет контактную зону барьера;

3) в тонкодисперсном минеральном субстрате органо-минерального слоя повышенное содержание влаги способствует проявлению процессов сорбции и механического осаждения элементов;

4) сильное переувлажнение в органогенном слое способствует растворению реакционно-способных фульвокислот, которые при наличии почвенных микроорганизмов способны к 
взаимодействию с поливалентными металлами (Al, $\mathrm{Cu}, \mathrm{Pb}, \mathrm{Zn}, \mathrm{Ni}$ ) и образованию комплексных катионов $\left[\mathrm{AlHSO}_{4}\right]^{+},\left[\mathrm{AlHSO}_{4}\right]^{2+},\left[\mathrm{CuHSO}_{4}\right]^{+}$и протонов $\left[\mathrm{H}^{+}\right][$Перминова, 2008].

В период ливневых дождей, при температуре почвы выше 15 градусов, растворимость многих химических компонентов в почвенном пространстве резко повышается [Иванов, 1994]. Содержание элементов, перешедших в раствор, определяется их миграционной активностью и для различных соединений неодинакова [Махинов, Махинова, 2015]. Миграционная активность элементов в почвах - есть следствие проявления химических свойств, способствующих образованию его растворимых форм или соединений при увлажнении, способных к миграции в составе почвенных растворов [Makhinova and et., 2013].

Миграционная активность элементов определяет состав почвенно-геохимических потоков, а частота их встречаемости - геохимические зоны их миграции [Махинова с соавт., 2012]. Интенсификация почвенно-геохимических потоков и вынос растворенных веществ при невысокой сорбции подчиняется закону гравитационной силы [Смагин, 2003]:

$$
\mathrm{F}_{\mathrm{g}}=\mathrm{P}_{\mathrm{b}} \mathrm{gh}=\left[\mathrm{P}_{\mathrm{b}}\left(\mathrm{W}-\mathrm{W}_{\mathrm{m}}\right)\left(\mathrm{W}_{\mathrm{p}}-\mathrm{W}_{\mathrm{m}}\right)_{\mathrm{z}}(\mathrm{g} / \mathrm{L})\right](\sin \alpha)=[\mathrm{M} \mathrm{g} / \mathrm{L}](\sin \alpha),
$$

где $\mathrm{F}_{\mathrm{g}}$ - гравитационные силы миграционных потоков;

$\mathrm{P}_{\mathrm{b}}$ - плотность почвы;

$\mathrm{g}$ - ускорение силы тяжести;

h - высота мокрой почвы; W - влажность почвы;

$\mathrm{W}_{\mathrm{p}}$ и $\mathrm{W}_{\mathrm{m}}$ - полная и максимальная влагоемкость почвы;

M - запасы подвижной влаги;

$\mathrm{L}$ - активная пористость;

$\mathrm{z}$ - координата;

$\sin \alpha-$ уклон поверхности.

Почвенно-геохимические потоки осуществляют массоперенос растворимых веществ и диспергированных фракций по поровому пространству почв. Движение потоков контролируется условиями водной миграции:

$$
\mathrm{J}_{\mathrm{m}} \mathrm{V}_{\mathrm{c}}=\left[\mathrm{F}_{\mathrm{g}}(\mathrm{M} / \mathrm{L}) \mathrm{C}_{\mathrm{m}} \mathrm{P}_{\mathrm{b}} \sin \alpha\right],
$$

где $\mathrm{J}_{\mathrm{m}}$ - интенсивность массопереноса;

$\mathrm{V}_{\mathrm{c}}$ - скорость передвижения почвенного раствора по поровому пространству;

$\mathrm{C}_{\mathrm{m}}$ - общая концентрация элементов.

Транспортирующая способность геохимического потока является функцией характеристик почвы и рельефа. Миграция элементов в почвенном пространстве чаще всего происходит за счет фильтрации обогащенного почвенного раствора в двух направлениях: а) нисходящие потоки и б) боковые, обусловленные образованием напора в условиях наклонной поверхности.

В условиях непрерывного безнапорного режима фильтрации почвенного раствора, pacпределение концентраций некоторых химических элементов ( $\mathrm{Fe}, \mathrm{Mn}, \mathrm{Zn}, \mathrm{Cu}$ ) в почвенном пространстве, в большей степени, согласуется с содержанием агрессивных фракций гумусовых веществ, а такие элементы, как $\mathrm{Co}$, Ni обнаруживают корреляцию с содержанием и распределением илистой фракции, что косвенно указывает на явление сорбции. Гумусовые кислоты чаще всего образуют комплексные соединения с микроэлементами, находящимися в почве при поступлении с техногенными выбросами.

Отличительной особенностью почв Приохотья является накопление в них поливалентных металлов (Fe, $\mathrm{Al}, \mathrm{Cu}, \mathrm{Zn})$, относительно фона и их взаимодействие с раствором реакционно-способных органических кислот (агрессивными фракциями гуминовых и фульвокислот). Исследования показали, что геохимическая активность катионов образовывать соединения с гумусовыми веществами в 200 м зоне от источников загрязнения можно располо- 
жить в ряд: $\mathrm{Fe}^{3+}>\mathrm{Al}^{3+}>\mathrm{Fe}^{2+}>>\mathrm{Zn}^{2+}>\mathrm{Cu}^{2+}>\mathrm{Pb}^{2+}>\mathrm{Co}^{2+}$. Положение металлов в этом ряду зависит от их концентрации в почвах, природы гумусовых кислот и $\mathrm{pH}$ в почвенном пространстве. С увеличением расстояния влияние источников загрязнения постепенно ослабевает [Глазовская, 2007]. Снижение концентраций некоторых химических компонентов вызывает изменения в ряду активности. В этих условиях высокие концентрации железа и марганца в почвах, обусловленные региональным геохимическим фоном территории, связывают агрессивные фракции гумусовых кислот, выполняя «роль разгрузки» геохимических потоков, образуют буферные зоны и способствуют снижению миграционной активности некоторых элементов $(\mathrm{Cu}, \mathrm{Pb}, \mathrm{Zn})$ или их осаждению [Варшал, 1993].

При напорном боковом движении насыщенного почвенного раствора концентрация элементов в определенных условиях возрастает и способствует интенсификации процессов обмена, окисления и явлению сорбции [Перминова, 2008]. Как правило, геохимические преобразования в этих условиях приводят к возникновению зон концентраций элементов. Особенно ярко это проявляется в условиях высокого содержания органических тонкодисперсных фракций и органоминеральных веществ в почвенном пространстве.

Выводы. Анализ экологических последствий разработки россыпных месторождений в Приохотье позволил выявить их влияние на состояние ландшафтов и определить условия миграционной активности химических компонентов.

1. Экологическая безопасность территории в границах земельного отвода и прилегающих к нему районах, определяется географическими условиями размещения источников загрязнения и их управлением. Задача по управлению рисками негативных последствий эксплуатации месторождения остается крайне важной и требует проведения многолетнего мониторинга.

2. Миграция химических элементов и их соединений в почвенном пространстве наиболее ярко проявляется в радиусе 250-300 м от источника загрязнения (отвалы вскрыши, отстойники) и контролируется климатическими условиями, которые характеризуются увлажнением, длительностью безморозного периода и концентрациями агрессивных фракций гумусовых кислот. На условия миграции также оказывают влияние рельеф, мощность и состав рыхлых отложений.

3. Геохимическая активность элементов определяет ряды их миграционной активности и состав почвенно-геохимических потоков. Косвенным показателем состояния почвенногеохимических потоков является постоянство концентраций элементов-индикаторов в почвенном пространстве, а частота их встречаемости определяет зоны геохимической миграции химических компонентов.

4. Высокие концентрации железа и марганца в почвах Приохотья связывают агрессивные фракции органических кислот, создают буферные зоны и способствуют снижению миграционной активности некоторых элементов $(\mathrm{Cu}, \mathrm{Zn}, \mathrm{Pb})$ в почвенных растворах или их осаждению.

5. Процессы разложения органики в присутствии бактерий, способствуют выделению тепловой энергии и активации явлений сорбции элементов на глинистых минералах и тонких фракциях органического вещества размером менее 2-3 мкм.

Таким образом, почвенное пространство, аккумулирующее элементы и их соединения, является зоной разгрузки геохимического потока, а содержание и качество органического вещества контролируют интенсификацию механизмов сорбции и, соответственно, степень загрязнения почв.

Благодарности. Исследование выполнено при поддержке гранта Российского научного фонда в рамках Комплексной программы Дальневосточного отделения РАН (проект № 0294-2015-0030).

\section{СПИСОК ЛИТЕРАТУРЫ}

1. Бельчикова Н.П. Определение гумуса почв по методу И.В. Тюрина // Агрохимические методы исследования почв. М.: Наука, 1975. С. 56-62. 
2. Варшал Г.М., Велюханова Т.К., Кощеева И.Я. Геохимическая роль гумусовых кислот в миграции элементов // Гуминовые вещества в биосфере. М.: Наука, 1993. С. 69-79.

3. Вернадский В.И. Проблемы биогеохимии // Труды Биогеохимической лаборатории АН СССР, М. 1980. Т. 158. С. 10-226.

4. Глазовская М.А. Геохимия природных и техногенных ландшафтов. М., 2007. 321 с.

5. Иванов В.В. Экологическая геохимия элементов. М.: Недра, 1994. 117 с.

6. Ивашов П.В., Сиротский С.Е. Биогеохимические особенности растений бассейна р. Ургал // Эколого-биогеохимические исследования на Дальнем Востоке. Владивосток: Дальнаука, 1996. С. 33-45.

7. Касимов Н.С., Глазовская М.А., Перельман А.И. Основные понятия геохимии ландшафтов, существенные для фонового мониторинга // Ландшафтно-геохимические основы фонового мониторинга прир.среды. М.: Наука,1989. С. 8-25.

8. Махинова А.Ф. Почвенный покров Нижнего Приамурья. Владивосток: ДВО РАН, $1989.144 \mathrm{c}$.

9. Махинова А.Ф., Махинов А.Н. Ермошин В.В. Основные геохимические потоки в ландшафтах бассейна р. Амур (в пределах российской территории) // Геохимия ландшафтов и география почв: Докл. Всерос. Научн. Конф. (к 100-летию М.А. Глазовской). М., 2012. С. 215-218.

10. Махинова А.Ф., Махинов А.Н. Купиова B.A., Liu Shuguang, Ермошин B.B. // Ландшафтно-геохимическое районировании бассейна р. Амур (Российская часть) Тихоокеанская геология. Т. 33, № 2, 2014. С. 76-89.

11. Махинов А.Н, Махинова А.Ф., Шевиов М.Н., Головкин С.С. Влияние разработки россыпных месторождений Приохотья на состояние водных объектов // Вестник ТОГУ, 2014. № 3 (34). C. 103-112.

12. Махинов А.Н., Махинова А.Ф. Особенности формирования почвенногеохимических полей бассейна р. АМУР: анализ структур и картографирование// ИнтерКарто/ИнтерГИС-21: Устойчивое развитие территорий: картографо-геоинформационное обеспечение. Материалы межд. конф. Краснодар, Сочи, Сува (Фиджи) 12-19 ноября 2015. Краснодар: Кубанский ГУ, 2015. С. 310-317.

13. Новороикий П.В. Климатические изменения в бассейне Амура за последние 115 лет // Метеорология и гидрология, 2007. № 2. С. 43-53.

14. Перминова И.В. Гуминовые вещества - вызов химикам XXI века // Химия и жизнь, №1. 2008. C. 50-55.

15. Смагин A.B. Теория и методы оценки физического состояния почв // Почвоведение. 2003. № 3. С. 328-341.

16. Труфанов А.И. О миграции железа и марганца в зоне гипергенеза юга Дальнего Востока // Природные зоны юга Дальнего Востока / Вопросы географии Дальнего Востока. Хабаровск: ХабКНИИ, 1975. Сб. 15. С. 147-154.

17. Шустов С.Б., Шустова Л.В. Химические основы экологии. М.: Просвещение. 1995. $240 \mathrm{c}$.

18. Alexandra F. Makhinova, Alexey N. Makhinov. Risk assessment of soil degradation and possible soil recultivation in mining in Priokhotie region // The $14^{\text {th }}$ Meeting. Sept. 14-19, 2008. V.1. 273-276. (in Russian).

19. Makhinova A.F., Makhinov A.N., Kuptsova V.A., Yermoshin V.V. Geochemical differentiation of soil in the Amur Basin (Russian Part) // Journal of Geochemical Exploration. Vol. 45. No. 6. 2013. P. 89-98. (in Russian).

20. Урьев Н.Б. Высококонцентрированные дисперсные системы. М., 1980. 320 с.

21. Щукин Е.Д., Перизов А.В., Амелина Е.А. Коллоидная химия, М., 1982. 385 с.

22. Muller J-P., Manceau A., Calas G. et al. Crystal chemistry of kaolinite and Fe-Mn oxide: relation with formation conditions of low temperature systems // American J. of Sci. 1995. V. 295. Pp. 1115-1155.

23. Senesi N., Loffredo E. Metal Iron Complexation by Soil Humic Substance // Chemical Processes in Soils. Madison: Soil Science Society of America, 2005. Pp. 563-617. 
24. Schlegel M.L., Manceau A., Charlet L., Hazemann J-1. Adsorption mechanisms of Zn on hectorite as function of time, $\mathrm{pH}$, and ionic strength //Amer. J. of Sci. 2001. V. 301. Pp. 798-830.

\title{
A.N. Makhinov ${ }^{1}$, A.F. Makhinova ${ }^{2}$ \\ ANALYSIS OF THE ENVIRONMENTAL CONDITIONS OF LANDSCAPES UNDER MINING DEVELOPMENT IN PRIOKHOTJE: ASSESSMENT METHODS AND MAPPING
}

\begin{abstract}
The paper presents landscape and geochemical characteristics, as well as identifies the sources of pollution of soil and surface watercourses in the Conder mining field, located in the extreme natural conditions. Chemical elements migration mechanisms and factors are described. Spatial heterogeneity of concentrations of chemical elements is considered as a function of element migration activity within organo-mineral complexes. The authors also analyze the state and regularities of natural and anthropogenic soil structures; show the role of natural and anthropogenic factors in the formation of water quality; investigate the conditions of the elements migration in the surface waters of different origin; formulate key principles of natural resource management, environmentally adapted to mountain specifics of northern regions of the Far East.
\end{abstract}

Kew words: chemical pollution, landscapes, migration activity.

Acknowledgement. The study was supported by Russian Foundation for Basic Research (project № 0294-2015-0030).

\section{REFERENCES}

1. Bel'chikova N.P. Opredelenie gumusa pochv po metodu I.V. Tjurina // Agrohimicheskie metody issledovanija pochv [Determination of soil humus by method of I. V. Tyurin // Agrochemical methods of soil investigation]. M.: Nauka, 1975. Pp. 56-62 (in Russian).

2. Varshal G.M., Veljuhanova T.K., Koshheeva I.Ja. Geohimicheskaja rol' gumusovyh kislot $\mathrm{v}$ migracii jelementov // Guminovye veshhestva $\mathrm{v}$ biosfere [Geochemical role of humic acids in migration of elements // Humic substances in biosphere]. M.: Nauka, 1993. Pp. 69-79 (in Russian).

3. Vernadskij V.I. Problemy biogeohimii // Trudy Biogeohimicheskoj laboratorii AN SSSR [Problems of biogeochemistry // Proceedings of the Biogeochemical laboratory of the USSR Academy of Sciences]. M., 1980. T. 158. Pp. 10-226 (in Russian).

4. Glazovskaja M.A. Geohimija prirodnyh i tehnogennyh landshaftov [Geochemistry of natural and technogenic landscapes]. M., 2007. 321 p. (in Russian).

5. Ivanov V.V. Jekologicheskaja geohimija jelementov [Ecological Geochemistry of elements]. M.: Nedra, 1994. 117 p. (in Russian).

6. Ivashov P.V., Sirotskij S.E. Biogeohimicheskie osobennosti rastenij bassejna r. Urgal // Jekologo-biogeohimicheskie issledovanija na Dal'nem Vostoke [Biogeochemical characteristics of plants of the basin of the Urgal river // Ecological and biogeochemical studies in the far East]. Vladivostok: Dal'nauka, 1996. Pp. 33-45 (in Russian).

7. Kasimov N.S., Glazovskaja M.A., Perel'man A.I. Osnovnye ponjatija geohimii landshaftov, sushhestvennye dlja fonovogo monitoringa // Landshaftno-geohimicheskie osnovy fonovogo monitoringa prirodnoj sredy [The basic concepts of landscape Geochemistry, which are essential to background monitoring // Landscape-geochemical basis of background monitoring of natural environment]. M.: Nauka, 1989. Pp. 8-25 (in Russian).

${ }^{1}$ IWEP FEB RAS Vice-Director on Science Matters, D. Geogr., Prof. Dep. of engineering systems and technosphere safety, Pacific State University, Khabarovsk, Russia; e-mail: amakhinov@mail.ru.

${ }^{2}$ FEB RAS, Ph.D. (Geogr.), senior researcher, Soil Ecology Laboratory, Khabarovsk, Russia; e-mail: mahinova@ivep.as.khb.ru. 
8. Mahinova A.F. Pochvennyj pokrov Nizhnego Priamur'ja [The soil cover of the Lower Amur region]. Vladivostok: DVO RAN, 1989.144 p (in Russian).

9. Mahinova A.F., Mahinov A.N. Ermoshin V.V. Osnovnye geohimicheskie potoki v landshaftah bassejna r. Amur (v predelah rossijskoj territorii) // Geohimija landshaftov i geografija pochv [Major geochemical flows in landscapes of the Amur river basin (within the Russian territory) // Geochemistry of landscapes and soil geography]: Dokl. Vseros. Nauchn. Konf. (k 100-letiju M.A. Glazovskoj). M., 2012. Pp. 215-218 (in Russian).

10. Makhinova A.F., Makhinov A.N., Kuptsova V.A., Liu Shuguang, Yermoshin V.V. Landshaftno-geokhimicheskoe rajonirovanii bassejna r. Amur (Rossijskaya chast') [Landscape Geochemical Zoning of the Amur Basin (Russian Territory)] // Journal of Pacific Geology. Vol. 33. No. 2. 2014. Pp. 76-89.

11. Mahinov A.N., Mahinova A.F., Shevtsov M.N., Golovkin S.S. Vliyanie razrabotki rossypnykh mestorozhdenij Priokhot'ya na sostoyanie vodnykh ob'ektov [Influence of the Development of Placer Deposits Near Okhotsk Sea on the Bodies of Water State] // Vestnik TOGU, 2014, \# 3 (34). Pp. 103-112.

12. Makhinov A.N., Makhinova A.F. Osobennosti formirovaniya pochvenno-geokhimicheskikh polej bassejna r. AMUR: analiz struktur i kartografirovanie [Formation specifics of soil-geocamical fields in the soil space of the Amur r. basin: structure and mapping] // InterCarto/InterGIS-21: Sustainable Developmant of Territory: Cartography and GI Support. Proc. Int. Conf. Krasnodar, Sochi, Suva(Figie). 12-19 november 2015. Kuban: GSU. Pp. 310-317 (in Russian).

13. Novorockij P.V. Klimaticheskie izmenenija v bassejne Amura za poslednie 115 let [Climate change in the Amur basin in the last 115 years]// Meteorologija i gidrologija, 2007. № 2. Pp. 43-53 (in Russian).

14. Perminova I.V. Guminovye veshhestva - vyzov himikam XXI veka [Humic substances a challenge to chemists XXI century] // Himija i zhizn', №1, 2008. Pp. 50-55 (in Russian).

15. Smagin A.V. Teorija i metody ocenki fizicheskogo sostojanija pochv [Theory and methods of assessing the physical condition of the soil]// Pochvovedenie. 2003. № 3. Pp. 328-341 (in Russian).

16. Trufanov A.I. O migracii zheleza i marganca v zone gipergeneza juga Dal'nego Vostoka [About the migration of iron and manganese in the supergene zone of the southern Far East] // Prirodnye zony juga Dal'nego Vostoka / Voprosy geografii Dal'nego Vostoka. Habarovsk: HabKNII, 1975. Sb. 15. Pp. 147-154 (in Russian).

17. Shustov S.B., Shustova L.V. Himicheskie osnovy jekologii [Chemical basis of ecology]. M.: Prosveshhenie. 1995. 240 p. (in Russian).

18. Alexandra F. Makhinova, Alexey N. Makhinov. Risk assessment of soil degradation and possible soil recultivation in mining in Priokhotie region // The $14^{\text {th }}$ Meeting. Sept. 14-19, 2008. V. 1. Pp. 273-276. (in Russian).

19. Makhinova A.F., Makhinov A.N., Kuptsova V.A., Yermoshin V.V. Geochemical differentiation of soil in the Amur Basin (Russian Part) // Journal of Geochemical Exploration. Vol. 45. No. 6. 2013. Pp. 89-98. (in Russian).

20. Uriev N.B. Vysokokontsentrirovannye dispersnye sistemy. [Highly concentrated dispersions]. Moscow, 1980. 320 p. (in Russian).

21. Schukin ED, Pertsov AV, Amelina EA. Kolloidnaya khimiya [Colloid chemistry]. M., 1982. 385 p. (in Russian).

22. Muller J-P., Manceau A., Calas G. et al. Crystal chemistry of kaolinite and Fe-Mn oxide: relation with formation conditions of low temperature systems //American J. of Sci. 1995. V. 295. Pp. 1115-1155.

23. Senesi N., Loffredo E. Metal Iron Complexation by Soil Humic Substance // Chemical Processes in Soils. Madison: Soil Science Society of America, 2005. Pp. 563-617.

24. Schlegel M.L., Manceau A., Charlet L., Hazemann J-1. Adsorption mechanisms of Zn on hectorite as function of time, $\mathrm{pH}$, and ionic strength // Amer. J. of Sci. 2001.V. 301. Pp. 798-830. 